\title{
Dynamic Relationship Between Real Export, Real Import, Real Exchange Rate, Labor Force and Real Gross Domestic Product in Malaysia
}

\author{
Emilda Hashim ${ }^{1}$, Norimah Rambeli ${ }^{1}$, Asmawi Hashim ${ }^{1}$, Norasibah Abdul Jali1 ${ }^{1}$, Shahrun Nizam Abdul Aziz ${ }^{1}$ \& Noor \\ Al Huda Abdul Karim ${ }^{1}$ \\ ${ }^{1}$ Faculty of Management and Economics, Universiti Pendidikan Sultan Idris, Tanjung Malim, Perak, Malaysia \\ Correspondence: Emilda Hashim, Faculty of Management and Economics, Universiti Pendidikan Sultan Idris, \\ Tanjung Malim, Perak, Malaysia.
}

Received: October 10, 2019

Accepted: November 5, 2019

Online Published: December 23, 2019

doi:10.5430/rwe.v10n5p20

URL: https://doi.org/10.5430/rwe.v10n5p20

\begin{abstract}
This study examined short run and long run relationship between endogenous and exogenous variables. Specifically, it studied the relationship between real export, real import, labor force participation and real effective exchange rate (REER) and real GDP in Malaysia from 1988 to 2017. These variables were tested in various tests, namely, unit root test, granger causality test, vector autoregressive (VAR), Johansen Juselius test and Error Correction Term (ECT). The result revealed that all variables were non-stationary at the level form and stationary at first difference in ADF unit root test. The findings also exhibited the existence of bilateral relationships between real export and real GDP, real import and real GDP, as well as labor and real GDP. Nonetheless, there were no relationship found between REER and real GDP. On the other hand, in VAR, the lag optimum was lag 10 because it indicated the smallest value of AIC. Moreover, for Johansen Juselius cointegration test, it showed two cointegrated vector at both, 5\% and 1\%, level in trace test. In addition, Max-Eigen value test indicated two cointegrated vector at 0.05 and one cointegrated vector at 0.01 . As for the Wald test, there were long run cointegration relationship between real GDP and its determinants, namely real export, real import, labor and REER. Apparently, Malaysia, as a small open economy, has relied heavily on foreign trade. Consequently, our domestic economic performance is susceptible to the changes in international markets and exchange rate. Therefore, suitable international policy implementation is vital to ensure Malaysian economy will be able to adjust to current global changes.
\end{abstract}

Keywords: dynamic relationship, real GDP, macroeconomic variables, econometrics testing, Malaysia

\section{Introduction}

Each nation measures their national yearly income using Gross Domestic Product (GDP) for nation's economic performances and its development purposes. We can also compare GDP data between countries to determine economic situation of these countries. GDP is commonly used as an indicator of the economic health of a country, as well as a gauge of a country's standard of living. Since the mode of measuring GDP is uniform from country to country, GDP can be used to compare the productivity of various countries with a high degree of accuracy.

Gross Domestic Product (GDP) is the market value of all new final goods and services produced in an economy in one year. There are many components of economy which can change the value of GDP like consumption, investment, government purchases and net export. Moreover, the labor force participation and real effective exchange rate (REER) can also be the reason why the value of GDP always different between the years. In this study, researcher will investigate the relationship between real export, real import, labor force participation and REER toward the value of real GDP from 1988 to 2017 in Malaysia (Petrenko, Vechkinzova and Antonov, 2019).

In Malaysia, government plays a very important role to increase the value of GDP. Government can implement some policies which will enhance the power of economy (Hussian et al., 2019). When a nation with higher value of GDP, it can attract more investors to invest their capitals into our country (Mayorova, 2019). In another word, the more capital flows in, the more advanced a country can be. So, government needs to promote their export, reduce the quantity of import, invest in human capital development and some more which can benefit the economy. Either a country adopted fixed exchange rate regime or flexible exchange rate regime, it also will influence the value of GDP 
in its country. Therefore, it can conclude that government is very vital to promote an economy. The motives of this study are as follows:-

-To investigate the long run relationship between endogenous and exogenous variables.

- To investigate the short run relationship between endogenous and exogenous variables.

Before further investigation, this study performs the trend analysis of each data series to observe the data series movement through time trend.

\section{Trend Analysis of Time Series Data}

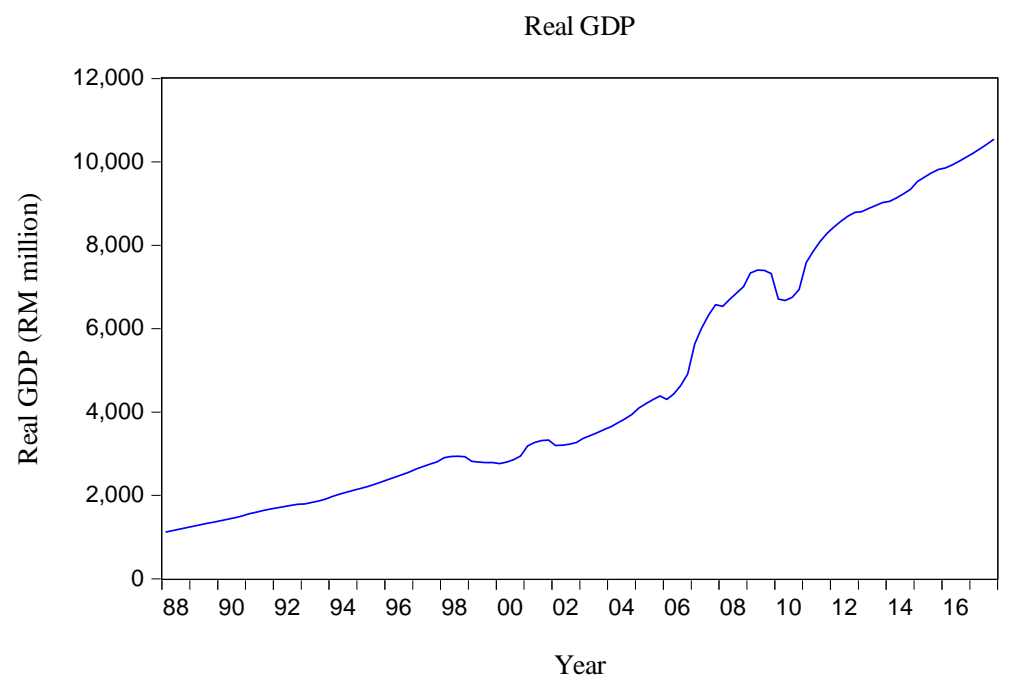

Figure 1. Real GDP in Malaysia from 1988 to 2017

Figure 1 in above shows about the real GDP in Malaysia from 1988 to 2017. In 1988Q1 (Quarter 1), real GDP was 1121.19 million and then it continuous to rise until 2928.86 million in 1988Q4. After that, real GDP started to decline from 2817.04 million in 1999Q1 to 2762.46 million, 2000Q1. However, in 2000Q2, it increased to 2798.68 million and continuous grow until 3330.14 million in 2001Q4. It dropped to 3196.02 million in 2002Q1 and raised quickly to 3202.45 million in 2002Q2. Then, real GDP rose continuously until 7402.57 million in 2009Q2 except declining in 2006Q1. After 2009Q2, real GDP declined from 7402.57 million (2009Q2) to 6750.22 million in 2010Q3. In 2010Q4, it raised back to 6938.42 and the trend raised non-stop until 10547.2 million in 2017Q4.

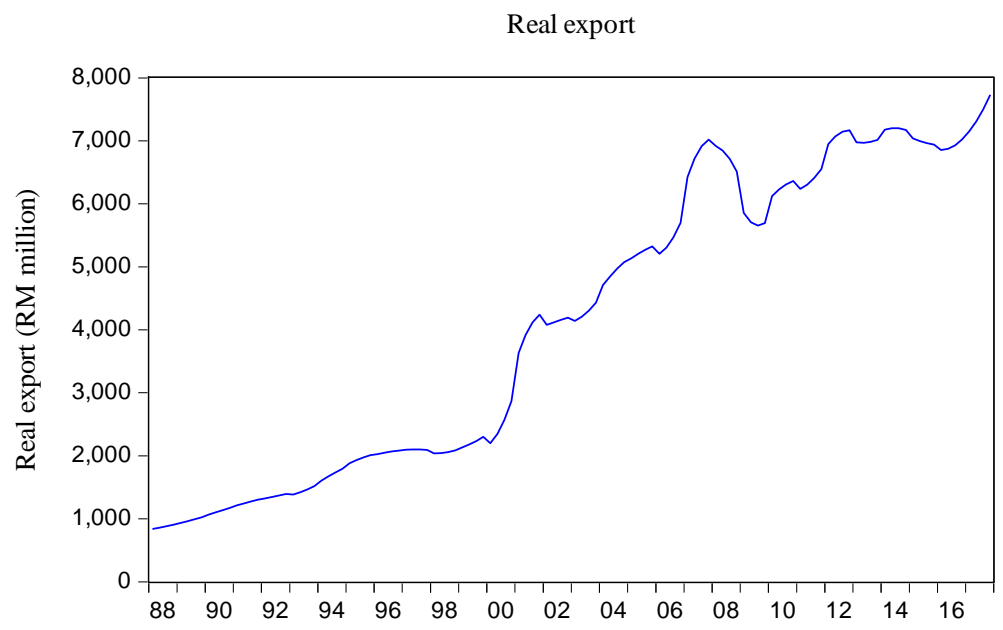

Figure 2. Real export in Malaysia from 1988 to 2017 
Figure 2 in above shows about the real export in Malaysia from 1988 to 2017. In 1988Q1, real export was 839.62873 million and then it raised until 1394.1621 million in 1992Q4. It dropped to 1386.8621 million in 1993Q1 and raised back to 1419.9747 million in 1993Q2. The increasing trend was continuous until 2100.5619 million in 1997Q2. However, it started to drop from 2100.1418 million in 1997Q3 until 2039.9534 million in 1998Q1. Then, it raised from 2042.966 million, 1998Q2 to 6711.1234 million in 2008Q3. After that, it dropped to 6512.0197 in 2008Q4 until 5653.4488 in 2009Q3. Then, it raised to 7167.7332 million in 2012Q4. However, it decreased to 6974.8454 million in 2013Q1 and grow back to 6983.7445 million in 2013Q3. But, dropped again from 7201.1933 million, 2014Q2 to 6852.9842 million, 2016Q1. After that, continuously to grow until 7730.0022 million in 2017Q4.

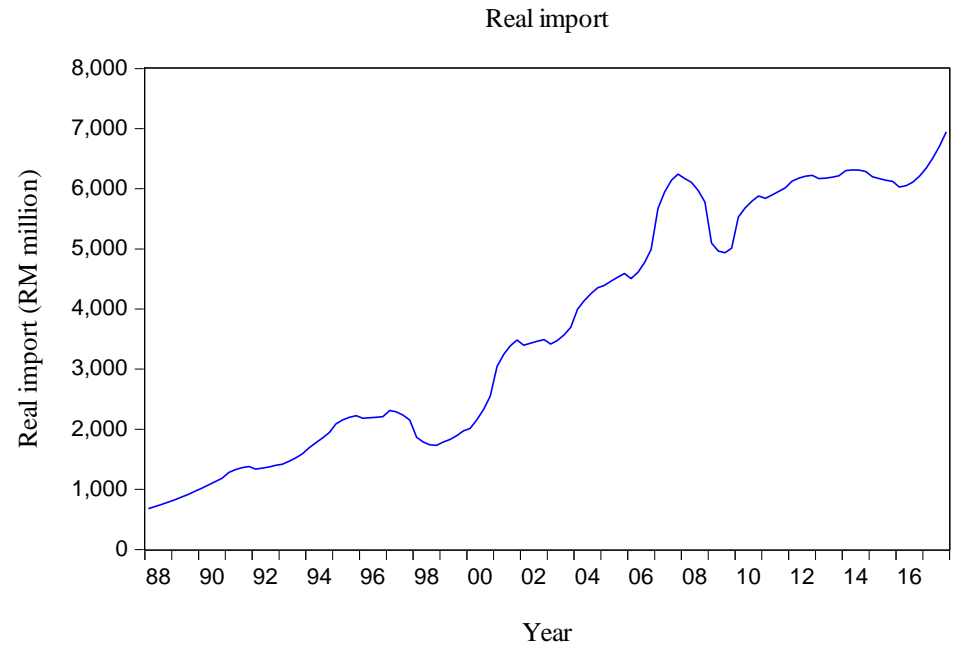

Figure 3. Real import in Malaysia from 1988 to 2017

Figure 3 in above shows about the real import in Malaysia from 1988 to 2017. In 1988Q1, real import was 680.59432 million and then it increased to 1381.3415 million in 1991Q4. After that, it dropped to 1338.9308 million in 1992Q1 and raised back to 1353.0047 million in 1992Q2. Then, continuously up until 2225.2459 million in 1995Q4 before dropped again to 2181.9978 million in 1996Q1. It increased from 2190.6379 million (1996Q2) to 2310.5987 million (1997Q1). But, it started to drop from 2310.5987 million (1997Q1) to 1731.4433 million (1998Q4). Starting from 1788.7467 million in 1999Q1, it began up until 3489.7761 million in 2002Q4. Then, it dropped to 3415.8024 million in 2003Q1 but raised quickly again to 3474.4519 million in 2003Q2 until 6245.4971 million in 2007Q4. However, it declined from 6171.0216 million in 2008Q1 to 4935.6241 million in 2009Q3. Then, it increased until 6950.064 million in 2017Q4 except period of 2011Q1, 2013Q2 and 2014Q4-2016Q1.

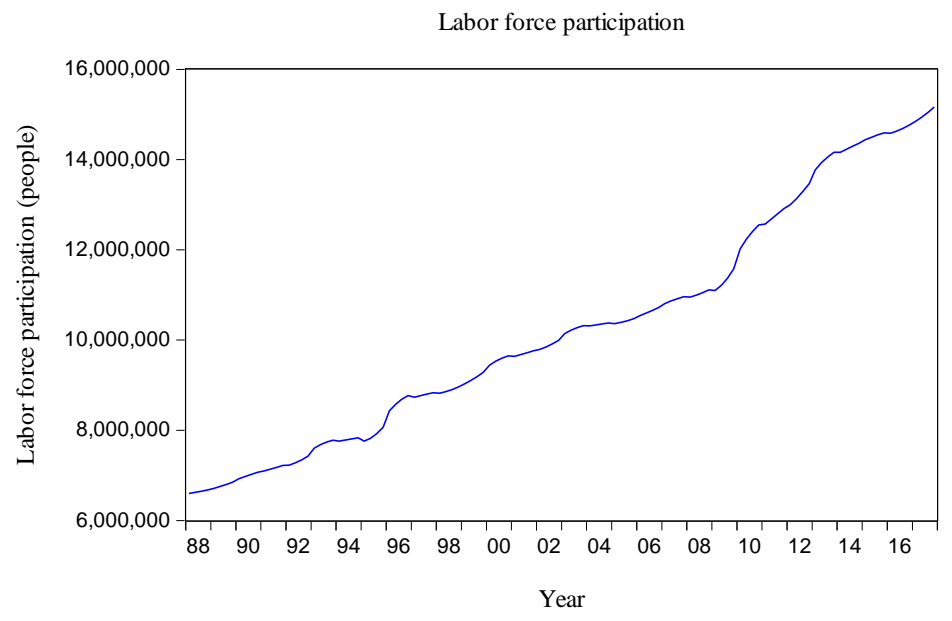

Figure 4. Labor force participation in Malaysia from 1988 to 2017 
Figure 4 above shows about the labor force participation in Malaysia from 1988 to 2017. In 1988Q1, labor force participation was 6600750 people and grow to 7832788 people in 1994Q4. It dropped to 7759038 people in 1995Q1 and raised back to 7822313 people in 1995Q2. It increased from 7924738 people in 1995Q3 to 15164475 people in 2017Q4. Labor force participation is always keep growing from 1988Q1 to 2017Q4, although in some period, it will decline but it was only slightly declined and can be raised back quickly in very short period.

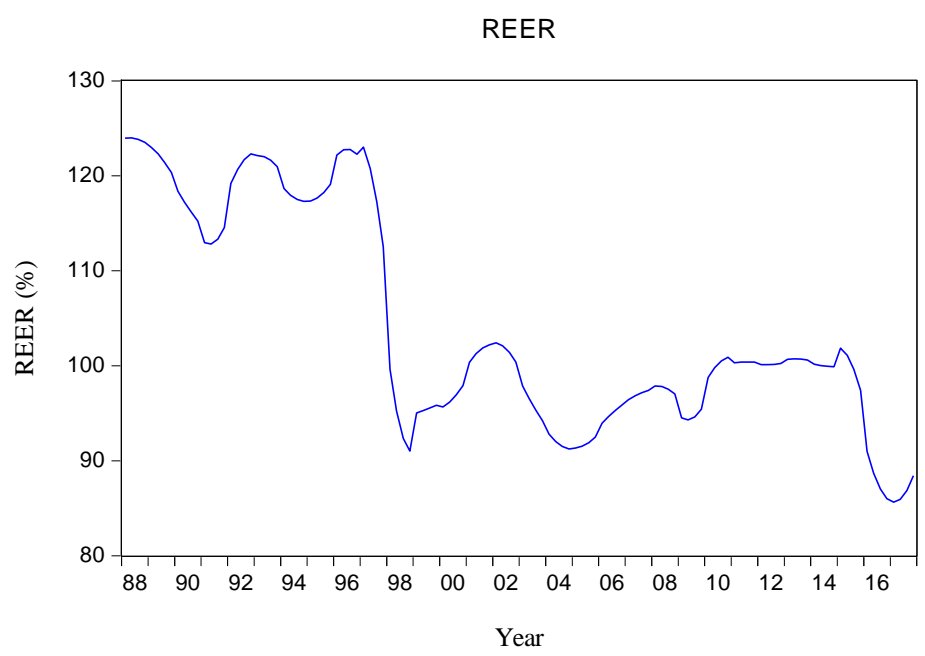

Figure 5. Real effective exchange rate in Malaysia from 1988 to 2017

Figure 5 above shows the real effective exchange rate (REER) in Malaysia from 1988 to 2017. REER was $123.9731 \%$ in $1988 Q 1$ and declined to $114.5402 \%$ in 1991Q4. It began to up from $119.2066 \%$ in $1992 \mathrm{Q} 1$ to $121.6345 \%$ in 1993Q3. After that, it decreased from $118.6615 \%$ in $1994 \mathrm{Q} 1$ to $117.352 \%$ in $1995 \mathrm{Q} 1$. Then, it increased back to $123.0021 \%$ in 1997Q1 and later it dropped until 91.02047\% in 1998Q4. Starting from 1999Q1, it is raising until $102.4198 \%$ in 2002Q1. It dropped again to $91.52817 \%$ in 2005Q2. It grew back until $97.87914 \%$ in 2008Q1 but later declined to $94.3056 \%$ in 2009Q2. Then, it raised slightly until 100.9074\% in 2010Q4 and keep stable in around 100\% until 2014Q2. But later, it continuously dropped until 88.42298\% in 2017Q4.

\section{Literature Review}

In this section we will discuss in detail the previous studies conducted by previous researchers. The issues and topics of discussion are based on the findings of the study as a whole. According to Dwi Kartikasari (2017) the relationship between export, import and investment which will influence the economic growth of Riau Islands Indonesia from 2009 to 2016. It showed that export is insignificant negatively to the economic growth. This is because that country is too focused on the exporting of natural gas and machinery and neglected the rest of economy. While, its import also indicated negative but significant to the economic growth. Moreover, for the independent variable of investment, it showed a positive and significant effect toward the economic growth. The researcher also suggested that adding more independent variables, extending the period of years and comparing with others countries in the future study. However, Mohsen (2015), examined the impact of oil and non-oil export on the economic growth of Syria from 1975 to 2010. The researcher found that oil and non-oil export are direct relationship with the economic growth. In the short run, the relationship between oil and non-oil export with the GDP are bidirectional causality. While, in the long run, non-oil export and GDP is in the bidirectional causality relation. Furthermore, unidirectional causality relationship between the oil exports to GDP in the long run. Researcher supports to improve the non-oil export, diversify the exports, simplify the procedures of export and improve also the domestic product in global markets. Synonym with the outcome by Çetintaş \& Barişik (2009), they analysed that there is a unidirectional causality relationship from economic growth to export. Besides, relationship between import and economic growth is bidirectional causality. Nowadays, import is playing a vital role in economic. Especially when production of a country raising, its national income also increase which will bring together the increasing of import. Then, it can conclude that if a country neglects the import growth, it may cause a slow-down in its economy. This result also consistence with Rambeli and Podivinsky (2013). The study focused on the dynamic relationship between international trade, which is presented by export and import. The result suggest for bilateral relationship between 
export and economic growth in Malaysia after the Asian Financial crisis in 1997. Not only export impact the economic growth in the long term, the import also gives the significant impact on economic growth. Refer to Kogid, Mulok, Ching, Lily, Ghazali \& Loganathan (2011) and Rambeli eta al. (2013) mentioned that import will spur the economic growth in the short run in Malaysia. However, in the long run, import will not reduce the growth. Malaysia can benefit the specialization and technological transfer from import goods and services. Researchers also stated that bilateral causality relationship between the import and economic growth. Economic growth can significant influence the import, and import also can influence economic growth significantly. Contradict with outcome by Bakari \& Mabrouki (2017) investigated the effect of exports, imports and economic growth in Turkey. It showed that no relationship between these variables. However, researchers found that from import to economic growth and from export to economic growth, both of them is bidirectional causality. They showed that same result when the researchers studied the same variables in Panama.

Based on the studied by Amir, Khan, \& Bilal (2015). they analysed the impact of educated labour force on economic growth of Pakistan. Researchers revealed that in the long run, human capital (educated labour force) is positively impact on economic growth. Besides, human capital has already been considered as a positive contributor to the growth of economic. This is because educated labour force will lead to long term sustainable growth and development in a country. Moreover, Hossain (2012) studied about the total labour force and GDP of Bangladesh from 2002 to 2009. It showed that labour force and GDP in Bangladesh is in a direct relationship. The correlation coefficient between the labour force and GDP showed a strong positive correlation which is 0.96 . So, when the labour force is increasing, then the GDP will also raising together with labour force.

Besides that, Shingil and Panshak (2017) studied about the real effective exchange rate and economic growth in the Turkey from 1970 to 2015. In the short run, the findings stated the relationship between the real effective exchange rate and economic growth is negatively related. However, in the long run, it is positive and significant between the real effective exchange rate and economic growth. Researchers also showed there is a uni-directional causality from real exchange rate to economic growth rate. So, it concluded that maintain the exchange rate can only drive the economic growth in the short run. However, in the long run, the increasing of real effective exchange can spur the growth. Nevertheless, AbuDalu, Ahmed, Almasaied, and Elgazoli (2014) analysed that the impact of domestic money supply (M1) and real effective exchange rate (REER) are positively and significantly to the growth rate of ASEAN-5 countries. Those are the long term and short run variables that can impact on the economic growth of ASEAN-5. Besides, researchers suggested that policymakers need to responsible on monitoring and sensitive to the economic environments of their trading partner. In addition, they also need to understand more deeply about the behaviour of significant impact variables for controlling the REER. Researchers also suggested to identify long run impact variables.

\section{Model Specification}

Inspired by Rambeli and Podivinsky (2016), the modelling proposes in this study is as follows;

\section{Augmented Modelling}

$$
\operatorname{Rg}_{1(t-1)}=\alpha_{0}+\alpha_{1} \operatorname{Re} \text { xport }_{t}+\alpha_{2} \text { Rimport }_{3}+\alpha_{i} \text { labor }_{t}+\alpha_{4} \operatorname{Re}_{\text {er }}+v_{t}
$$

Where, real gross domestic Product denotes as Rgdp, Rexport is real export, Rimport is real import, labor is stend for labor force in the market and real effective exchange rate is denotes as Reer. Subscript " $t$ " is time series data. While $\alpha_{0}$ is constant, $\alpha_{i}\left(\mathrm{i}=1,2,3\right.$, ) is coefficient. Finally $v_{t}$ is white noise error term. In this chapter, all data will be process through Augmented Dickey Fuller (ADF) unit root test, Granger Causality, Vector Autoregressive (VAR) and Johansen Juselius cointegration. 
Table 1. Augmented Dickey Fuller (ADF) Unit Root Test

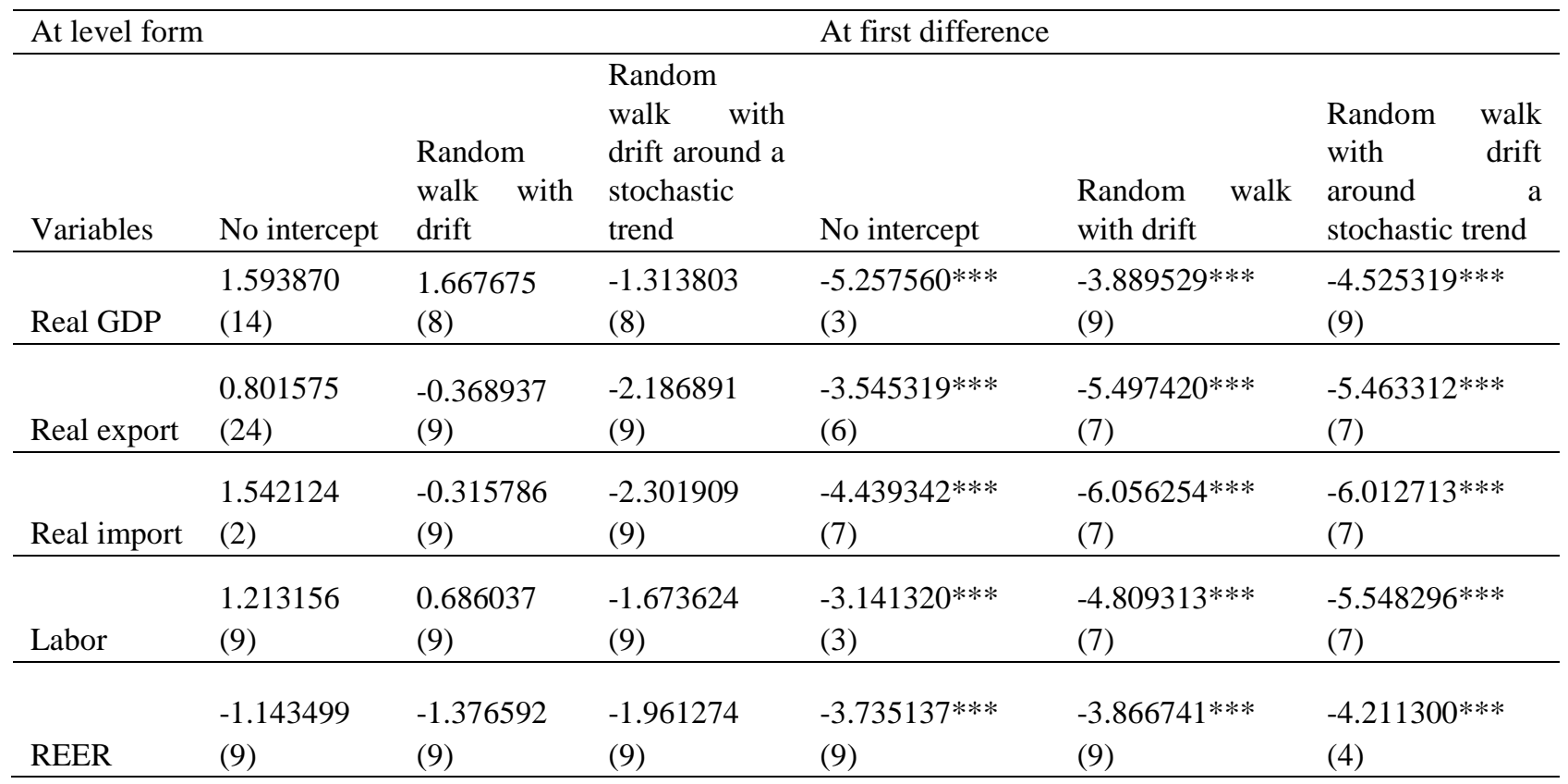

Note: $* *$ is indicated as significant at the $5 \%$ and $10 \%$.

Note: $* * *$ is indicated as significant at the $1 \%, 5 \%$ and $10 \%$

Table 1 shows the Augmented Dickey-Fuller (ADF) unit root test at level form and first difference with the consideration into no intercept, random walk with drift and random walk with drift around a stochastic trend. From the table, real GDP, real export, real import and REER are non-stationary at the level form, but stationary at the first difference. Thus, real GDP, real export, real import, labor force and REER are I (1) variables.

Table 2. Vector Autoregressive (VAR)

\begin{tabular}{ll}
\hline Lag & AIC \\
\hline 2 & 63.23825 \\
3 & 63.55413 \\
4 & 63.9179 \\
5 & 61.98866 \\
6 & 61.06532 \\
7 & 61.42221 \\
8 & 61.78381 \\
9 & 60.17681 \\
10 & 58.93996 \\
11 & 59.22091 \\
12 & 59.51196 \\
\hline
\end{tabular}

Table 2 shows about the results of VAR from lag 2 to lag 12. It records the value of Akaike Info Criterion (AIC) from lag 2 to lag 12. AIC at lag 10 is the minimum value. So, AIC at lag 10 shows the optimal lag. 
Table 3. Johansen Juselius (JJ) Test

\begin{tabular}{|c|c|c|c|c|c|c|c|}
\hline \multirow{2}{*}{\multicolumn{2}{|c|}{ Data Period }} & \multicolumn{6}{|c|}{ Cointegration system: } \\
\hline & & \multicolumn{6}{|c|}{ F ( Real GDP, Real Export, Real Import, Labor force participation, REER) } \\
\hline \multicolumn{2}{|c|}{ Hypothesis } & $\lambda$ Trace & $\begin{array}{l}5 \% \\
\text { critical } \\
\text { value }\end{array}$ & $\begin{array}{l}1 \% \text { critical } \\
\text { value }\end{array}$ & $\lambda \operatorname{Max}$ & $\begin{array}{l}5 \% \text { critical } \\
\text { value }\end{array}$ & $\begin{array}{l}1 \% \text { critical } \\
\text { value }\end{array}$ \\
\hline $\mathrm{H}_{0}$ & $\mathrm{H}_{1}$ & & & & & & \\
\hline $\mathrm{r}=\mathrm{O}$ & $r>0$ & $99.69360 * *$ & 68.52 & 76.07 & $43.70147 * *$ & 33.46 & 38.77 \\
\hline $\mathrm{r} \leq 1$ & $\mathrm{r}>1$ & $55.99214 * *$ & 47.21 & 54.46 & $27.88153^{*}$ & 27.07 & 32.24 \\
\hline$r \leq 2$ & $r>2$ & 28.11061 & 29.68 & 35.65 & 15.00083 & 20.97 & 25.52 \\
\hline$r \leq 3$ & $r>3$ & 13.10978 & 15.41 & 20.04 & 11.83759 & 14.07 & 18.63 \\
\hline$r \leq 4$ & $r>4$ & 1.272183 & 3.76 & 6.65 & 1.272183 & 3.76 & 6.65 \\
\hline
\end{tabular}

Note: The notation ' $r$ ' denotes the number of cointegrating vectors. $*(* *)$ denotes rejection of the hypothesis at the $5 \%(1 \%)$ level.

Table 3 shows the cointergation result. When $\mathrm{r}=0$, trace statistic value, 99.69360 is larger than the critical value at 0.05 and 0.01 which are 68.52 and 76.07 respectively. Then, the null hypothesis is rejected when $r=0$. While, at $r \leq 1$, trace statistic value, 55.99214 is also larger than 47.21 at 0.05 and 54.46 at 0.01 . Null hypothesis rejected when $r \leq 1$. Therefore, trace test indicated two cointegrating vector at both 5\% and 1\% level.Besides, for $\mathrm{r}=0$ in Max-Eigen statistic, its value is greater than 33.46 at 0.05 and 38.77 at 0.01 . So, null hypothesis is rejected. When $r \leq 1,27.88153$ is only bigger than critical value at 0.05 which is 27.07 . Therefore, Max-Eigen value test indicated two cointegrating vector at 0.05 and one cointegrating vector at 0.01 .

Table 4. Granger Causality Test

\begin{tabular}{|c|c|c|c|c|c|c|}
\hline Null Hypothesis: & Obs & $\begin{array}{l}\text { Number } \\
\text { of lag }\end{array}$ & F-Statistic & Prob. & Decision & Outcomes \\
\hline $\begin{array}{l}\text { REAL_EXPORT does not } \\
\text { Granger } \\
\text { REAL_GDP }\end{array}$ & & & 3.46214 & 0.0007 & Reject & $\begin{array}{l}\text { Real export causes real } \\
\text { GDP }\end{array}$ \\
\hline $\begin{array}{l}\text { REAL_GDP does not } \\
\text { Granger } \\
\text { REAL_EXPORT }\end{array}$ & 110 & 10 & 4.51472 & 4.E-05 & Reject & $\begin{array}{l}\text { Real GDP causes real } \\
\text { export }\end{array}$ \\
\hline $\begin{array}{l}\text { REAL_IMPORT does not } \\
\text { Granger } \\
\text { REAL_GDP }\end{array}$ & 110 & 10 & 5.82975 & 1.E-06 & Reject & $\begin{array}{l}\text { Real import causes real } \\
\text { GDP }\end{array}$ \\
\hline $\begin{array}{l}\text { REAL_GDP does not } \\
\text { Granger } \\
\text { REAL_IMPORT }\end{array}$ & & & 4.49916 & 4.E-05 & Reject & $\begin{array}{l}\text { Real GDP causes real } \\
\text { import }\end{array}$ \\
\hline $\begin{array}{l}\text { LABOR does not Granger } \\
\text { Cause REAL_GDP }\end{array}$ & 110 & 10 & 3.75678 & 0.0003 & Reject & $\begin{array}{l}\text { Labor } r \text { force } \\
\text { participation causes real } \\
\text { GDP }\end{array}$ \\
\hline $\begin{array}{l}\text { REAL_GDP does not } \\
\text { Granger Cause LABOR }\end{array}$ & & & 2.05061 & 0.0371 & Reject & $\begin{array}{l}\text { Real GDP causes labor } \\
\text { force participation }\end{array}$ \\
\hline $\begin{array}{l}\text { REER does not Granger } \\
\text { Cause REAL_GDP }\end{array}$ & & & 1.77730 & 0.0763 & Accept & $\begin{array}{l}\text { REER does not cause } \\
\text { real GDP }\end{array}$ \\
\hline $\begin{array}{l}\text { REAL_GDP does not } \\
\text { Granger Cause REER }\end{array}$ & 110 & 10 & 0.44201 & 0.9217 & Accept & $\begin{array}{l}\text { Real GDP does not } \\
\text { cause REER }\end{array}$ \\
\hline
\end{tabular}


Table 4 shows the findings on the granger causality between real export, real import, labor force participation and REER toward the real GDP. For the lag optimum $10, H_{0}$ is rejected between the real export and real GDP. So, there is bilateral relationship between real export and real GDP. It means that real export will granger cause real GDP and real GDP also can granger cause real export. Besides, $H_{0}$ is also rejected to test the relationship between real import and real GDP on lag 10. There is bilateral relationship among real import and real GDP. Real import will influence the value of real GDP, while real GDP also can influence the value of real import. Moreover, the relationship between labor force participation and real GDP are influenced among themselves. For the lag optimum $10, H_{0}$ is rejected. Then, this showed that bilateral relationship among labor force participation and real GDP. However, for the optimum lag 10, there is no relationship between REER and real GDP. This is because REER and real GDP does not granger cause among themselves.

\section{Conclusion}

These findings from this study give the vast impact on existence literature on related field. In overall, according to the result it can be suggest that to the government should diversify exports, simplify the export procedures, improve the industry, as well as boosting the quality, productivity, and competitiveness of the products in global markets. This is because the export productivity give the positive impact to the economic growth, thus support for the export led growth hypothesis as evidenced by the research conducted by Rambeli et al (2013) for Malaysia case. Therefore, it is possible if a few policies can be recommended for the country just to preserving the progress of international trade in the country. The suggested policies are;

- The government should implement effective macroeconomic policies in stabilizing its trade balance and liberalizing the country's trade, as well as attracting export-oriented foreign direct investment into the country.

- The government should ensure that the supply of well-equipped labour is adequate, as this would lead to a higher level of economic growth.

- A stable exchange rate policy is a must in maintaining good economic performance, as movements in the exchange rate may produce negative impacts on economic prosperity. The county may have to re-pegged the exchange rate like in year 1998.

Therefore as a small open economy, it is evident that Malaysia relies heavily on foreign trade. Hence, domestic economic performance is sensitive to the changes in international markets. Therefore, the suitable international policy is important in order to adjust with global changes.

\section{References}

AbuDalu, A., Ahmed, E.M., Almasaied, S.W., \& Elgazoli, A.I. (2014). The Real Effective Exchange Rate Impact on ASEAN-5 Economic Growth. Int J Econ Manag Science, 3(174), 2.

Amir, H., Khan, M., \& Bilal, K. (2015). Impact of educated labor force on Economic growth of Pakistan: A human capital perspective. European Online Journal of Natural and Social Sciences, 4(4), 814-823.

Bakari, S., \& Mabrouki, M. (2016). The Relationship among Exports, Imports and Economic Growth in Turkey.

Bakari, S., \& Mabrouki, M. (2017). Impact of exports and imports on economic growth: New evidence from Panama. Journal of Smart Economic Growth, 2(1), 67-79.

Çetintaş, H., \& Barişik, S. (2009). Export, import and economic growth: The case of transition economies. Transition Studies Review, 15(4), 636-649.

Denton, F.T., \& Spencer, B.G. (1997). Population, labour force and long-term economic growth. McMaster University, Faculty of Social Sciences, Program for Research on the Independence and Economic Security of the Older Population.

Hossain, M.I. (2012). Total labor force and GDP of Bangladesh: an analysis in between the year 2002-2009.

Hussain, H.I., Kamarudin, F., Thaker, H.M.T., \& Salem, M.A. (2019) Artificial Neural Network to Model Managerial Timing Decision: Non-Linear Evidence of Deviation from Target Leverage. International Journal of Computational Intelligence Systems, 12(2), 1282-1294.

Kartikasari, D. (2017). The Effect of Export, Import and Investment to Economic Growth of Riau Island Indonesia.

Khan, M. (2015). An ascertainment of multi-sectorial programs for trade and aid between Pakistan and South Korea; challenges, opportunities and way forward. Journal of Asian Business Strategy, 5(11), 240-251. 
Kogid, M., Mulok, D., Ching, K. S., Lily, J., Ghazali, F., \& Loganathan, N. (2011). Does import affect economic growth in Malaysia. Empirical Economics Letters, 10(3), 297-307.

Mayorova, E. (2019). Corporate social responsibility disclosure: evidence from the European retail sector. Entrepreneurship and Sustainability Issues, 7(2), 891- 905.

Mohsen, A.S. (2015). Effects of oil and non-oil exports on the economic growth of Syria. Academic Journal of Economic Studies, 1(2), 69-78.

Musa Esuwa Shingil, \& Yohanna Panshak. (2017). Exchange rate dynamics, Inflation and Economic Growth: Empirical Evidence from Turkish Economy. IOSR Journal of Humanities and Social Science, 22(9), 3.

Mustafa, S. A. (2016). The Effective Strategies in Companies' Performance Using the Partial Least Squares Approach. International Journal of Economics, Business and Management Studies, 3(2), 94-101.

Petrenko, Y., Vechkinzova, E., \& Antonov, V. (2019). Transition from the industrial clusters to the smart specialization of the regions in Kazakhstan. Insights into Regional Development, 1(2), 118-128.

Rambeli, N. (2004). Dynamic Relationship between Money, Output and Exchange Rate in Two Exchange Rate Regime. Unpublished article.

Rambeli, N., \& Podivinsky, J. (2013). A Study of Exogeneity Tests on Export-Led Growth Hypothesis: The Empirical Evidences on Post-Crisis Exchange Rate Regime in Malaysia. International Business Education Journal, 6(1), 7-20. Retrieved from http://ojs.upsi.edu.my/index.php/IBEJ/issue/view/184

Rambeli, N., Dayang-Affizzah, A.M., \& Hashim, E. (2016). The Effect of Foreign Direct Investment, Export and Employment on Economic Growth. International Journal of Academic Research in Business and Social Science, 6(11), 459-376.

Rambeli, N., Hashim, E., Hashim, A., Dayang Affizah, A.M., \& Podivinsky, J.M. (2017). Empirical analysis on exchange rate fluctuation and sectoral stock returns in Malaysia. Jurnal Ekonomi Malaysia, 51(1), 33-40.

Rambeli, N., Podivinsky, J., \& Jalil, N.A. (2019). The Re-examination of the Dynamic Relationship between Money, Output and Economic Growth in Malaysia. International Journal of Innovation, Creativity and Change, 5(2), 1812-1834.

Rambeli, N., Podivinsky, J., Hashim, A., \& Hashim, E. (2014) .Issues On Exchange Rate Volatility \& Exports Nexus - "A Case for Asean". Management Research Journal, 3(2014), 164-184. Retrieved from https://docs.wixstatic.com/ugd/7b8359_d4c26c246ac84c22ae1179729d6a6fa1.pdf 


\section{Appendix}

Error Correction Term (ECT)

Table 6. Error Correction term (ECT)

\begin{tabular}{lcc}
\hline Cointegrating Eq: & CointEq1 & CointEq2 \\
\hline REAL_GDP(-1) & 1.000000 & 0.000000 \\
\hline REAL_EXPORT(-1) & 0.000000 & 1.000000 \\
\hline REAL_IMPORT(-1) & 2.537760 & -0.630799 \\
\hline LABOR(-1) & $(0.47662)$ & $(0.13434)$ \\
\hline & {$[5.32447]$} & {$[-4.69540]$} \\
\hline REER(-1) & -0.00232 & -0.000199 \\
\hline & $(0.00024)$ & $(6.7 \mathrm{E}-05)$ \\
\hline C & {$[-9.72810]$} & {$[-2.95838]$} \\
\hline
\end{tabular}

Ect1 $(-1)=-983.5234+1 *$ real_gdp $(-1)+2.537760 *$ real_import $(-1)-0.002320$ * labor $(1)+102.4743 * \operatorname{reer}(-1)$

$\operatorname{Ect} 2(-1)=-4765.508+1 *$ real export $(-1)-0.630799 *$ real import $(-1)$ $-0.000199 *$ labor $(-1)+48.27788 * \operatorname{reer}(-1)$ 